\title{
THE EFFECT OF SHIFTS IN MEDIUM TYPES ON THE GROWTH AND MORPHOLOGY OF SPIRULINA PLATENSIS (ARTHROSPIRA PLATENSIS)
}

Yean-Chang Chen

Department of Aquaculture, National Taiwan Ocean University, Keelung, Taiwan, R.O.C., ycchen@mail.ntou.edu.tw

\section{Recommended Citation}

Chen, Yean-Chang (2011) "THE EFFECT OF SHIFTS IN MEDIUM TYPES ON THE GROWTH AND MORPHOLOGY OF SPIRULINA PLATENSIS (ARTHROSPIRA PLATENSIS)," Journal of Marine Science and Technology. Vol. 19: Iss. 5, Article 13.

DOI: $10.51400 / 2709-6998.2171$

Available at: https://jmstt.ntou.edu.tw/journal/vol19/iss5/13

This Research Article is brought to you for free and open access by Journal of Marine Science and Technology. It has been accepted for inclusion in Journal of Marine Science and Technology by an authorized editor of Journal of Marine Science and Technology. 


\section{THE EFFECT OF SHIFTS IN MEDIUM TYPES ON THE GROWTH AND MORPHOLOGY OF SPIRULINA PLATENSIS (ARTHROSPIRA PLATENSIS)}

\section{Acknowledgements}

The author sincerely thanks the eviewers for their kindly and helpful suggestions. Financial support from NSC grants 99-2321-B-019-005, COA grants 99-AS-5.3.1-ST-aQ, and NTOU-RD-AA-2010-102022, Taiwan is greatly appreciated. 


\title{
THE EFFECT OF SHIFTS IN MEDIUM TYPES ON THE GROWTH AND MORPHOLOGY OF SPIRULINA PLATENSIS (ARTHROSPIRA PLATENSIS)
}

\author{
Yean-Chang Chen*
}

Key words: Arthrospira, Spirulina platensis, Provasoli, Ultrastructure, Zarrouk

\begin{abstract}
In order to reduce the cultural cost and increase the biomass of Spirulina platensis cultures, two basic culture media were used in the present study, the Zarrouk (Z9) and Provasoli's enriched seawater (PES) media. They were re-modified into five media by adding varied concentrations of $\mathrm{NaCl}, \mathrm{NaHCO}_{3}$ and seawater (salinity). S. platensis could grow well in all of these media. The Z9 medium provided the best growth rate at the end of culture and the PES medium provided the best initial growth curve slope. After the media were shifted from PES to Z9, the long algal filaments fragmented to form many short filaments within 5 days of culture. Those short filaments then straightened into less spiral forms due to the ingrowths of active cell division after 7 days of culture. This media shifted batch culture is simple to operate with the lowest cost and the highest biomass in laboratory scale culture.
\end{abstract}

\section{INTRODUCTION}

It is widely recognized that microalgae can be used as animal feed and human food [3]. The nutritional value of microalgae has been substantiated by numerous studies and compared well with other conventional food products. The food potential of the genus Spirulina seems particularly promising. Spirulina filaments, may be easily separated from their medium, have high digestibility, a mild flavor, and contain up to $70 \%$ excellent quality protein [16]. Spirulina is commercially exploited for human food supplements, fodder, and pharmaceuticals such as anti-tumor drugs [6] and anti-HIV-1 [1]. Spirulina species are usually grown in open systems, such as raceway ponds and in closed photobioreactors [15] for mass

Paper submitted 09/16/10; received 01/31/11; accepted 02/25/11. Author for correspondence: Yean-Chang Chen (e-mail: ycchen@mail.ntou.edu.tw).

*Department of Aquaculture, National Taiwan Ocean University, Keelung. Taiwan, R.O.C. cultures. Despite the plethora of mass cultured Spirulina, little attention has focused on the impact of the media shift used in the production of Spirulina. Spirulina production as well as its photosynthetic activity and growth-physiology is greatly restricted by the culture media. There have been few studies that reported on the morphological changes involved with inducing and accelerating cell division when Spirulina has been cultivated in various media.

The aim of the present study was to increase the Spirulina biomass in batch cultures by shifting the cultures to different media. This attempt may reduce the cost of Spirulina platensis cultures, especially for ultrahigh-density cultures. Special attention was given to the morphological alterations of the alga, more surprising, was the response of Spirulina to the shift of media.

\section{MATERIALS AND METHODS}

\section{Algal Cultures and Media Preparations}

Stock cultures of Spirulina platensis, preserved in the laboratory of the Department of Aquaculture, National Taiwan Ocean University, Keelung, Taiwan, were used as the test materials.

Two modified media, Provasoli's enriched seawater (PES) medium [10] (Table 1) and Zarrouk (Z9) medium [19] (Table 2) were re-modified to five media as follows:

1. PES medium (as Table 1) in which the salinity of the seawater was reduced to $20 \%$. The $\mathrm{pH}$ value was 8.5 .

2. PEF medium in which the nutrients were the same as the PES medium, but freshwater was used instead of seawater with $16.8 \mathrm{~g} / \mathrm{L} \mathrm{NaHCO}_{3}$ added for a $\mathrm{pH}$ buffer and osmoregulant. The $\mathrm{pH}$ value was 9.7 .

3. $\mathrm{Z} 9$ medium (as Table 2), $\mathrm{pH}$ value was 9.7 .

4. Z9-1 medium, the same as Z9, but the concentration of $\mathrm{NaHCO}_{3}$ was reduced to half, and $8.4 \mathrm{~g} / \mathrm{L} \mathrm{NaCl}$ was added for osmotic balance. The $\mathrm{pH}$ value was 9.7 .

5. Z9-2 medium, the same as $\mathrm{Z9}$, but $\mathrm{NaCl}(16.8 \mathrm{~g} / \mathrm{L})$ was added instead of $\mathrm{NaHCO}_{3}$. The $\mathrm{pH}$ value was set to 8.5 by adding $\mathrm{NaOH}$. 
Table 1. the nutrient elements of Provasoli's enriched seawater (PES) medium (g/L of $\left.\mathrm{H}_{2} \mathrm{O}\right)$.

\begin{tabular}{cc|cc}
\hline $\mathrm{NaNO}_{3}$ & 75 & $\mathrm{CuSO}_{4} \cdot 5 \mathrm{H}_{2} \mathrm{O}$ & 0.01 \\
$\mathrm{NaH}_{2} \mathrm{PO}_{4} \cdot 2 \mathrm{H}_{2} \mathrm{O}$ & 5.6 & $\mathrm{ZnSO}_{4} \cdot 7 \mathrm{H}_{2} \mathrm{O}$ & 0.022 \\
$\mathrm{NH}_{4} \mathrm{Cl}$ & 26.8 & $\mathrm{CoCl}_{2} \cdot 6 \mathrm{H}_{2} \mathrm{O}$ & 0.01 \\
$\mathrm{Na}_{2} \mathrm{EDTA}$ & 4.36 & $\mathrm{MnCl}_{2} \cdot 4 \mathrm{H}_{2} \mathrm{O}$ & 0.18 \\
$\mathrm{FeCl}_{3} \cdot 6 \mathrm{H}_{2} \mathrm{O}$ & 3.15 & $\mathrm{NaMoO}_{4} \cdot 2 \mathrm{H}_{2} \mathrm{O}$ & 0.0063 \\
$\mathrm{Biotin}$ & 0.001 & $\mathrm{MgSO}_{4} \cdot 7 \mathrm{H}_{2} \mathrm{O}$ & 25 \\
$\mathrm{H}_{3} \mathrm{BO}_{3}$ & 2.24 & $\mathrm{Vitamin}_{12}$ & 0.001 \\
Thiamin $\mathrm{HCl}$ & 0.2 & & \\
(Vitamin $\left.\mathrm{B}_{1}\right)$ & & & \\
\hline
\end{tabular}

Add $1 \mathrm{~mL}$ of this stock solution to $1 \mathrm{~L}$ of seawater as PES medium.

Table 2. The nutrient elements of Zarrouk (Z9) medium.

\begin{tabular}{|c|c|c|c|}
\hline $\begin{array}{c}\mathrm{NaHCO}_{3} \\
\mathrm{KNO}_{3} \\
\mathrm{~K}_{2} \mathrm{SO}_{4} \\
\mathrm{NaCl} \\
\mathrm{H}_{3} \mathrm{PO}_{4} \\
\end{array}$ & $\begin{array}{c}16.8 \mathrm{~g} / \mathrm{L} \text { of water } \\
3.0 \\
1.0 \\
1.0 \\
0.25 \mathrm{~mL} / \mathrm{L} \text { of water }\end{array}$ & $\begin{array}{c}\mathrm{MgSO}_{4} \cdot 7 \mathrm{H}_{2} \mathrm{O} \\
\mathrm{CaCl}_{2} \\
\mathrm{FeSO}_{4} \\
\text { EDTA }\end{array}$ & $\begin{array}{c}0.20 \mathrm{~g} / \mathrm{L} \text { of water } \\
0.04 \\
0.0055 \\
\\
0.08\end{array}$ \\
\hline \multicolumn{4}{|c|}{ Plus $1 \mathrm{~mL}$ each of solutions $A$ and $B$ for each liter of the above. } \\
\hline Solution A (g/L of water) & & Solution B (g/L of water) & \\
\hline $\mathrm{H}_{3} \mathrm{BO}_{3}$ & 2.86 & $\mathrm{NH}_{4} \mathrm{VO}_{3}$ & $229 \times 10^{-4}$ \\
\hline $\mathrm{MnCl}_{2} \cdot 4 \mathrm{H}_{2} \mathrm{O}$ & 1.81 & $\mathrm{~K}_{2} \mathrm{Cr}\left(\mathrm{SO}_{4}\right)_{4} \cdot 24 \mathrm{H}_{2} \mathrm{O}$ & $960 \times 10^{-4}$ \\
\hline $\mathrm{ZnSO}_{4} \cdot 7 \mathrm{H}_{2} \mathrm{O}$ & 0.392 & $\mathrm{NiSO}_{4} \cdot 6 \mathrm{H}_{2} \mathrm{O}$ & $445 \times 10^{-4}$ \\
\hline $\mathrm{CuSO}_{4} \cdot 5 \mathrm{H}_{2} \mathrm{O}$ & 0.125 & $\mathrm{Na}_{2} \mathrm{WO}_{4} \cdot 2 \mathrm{H}_{2} \mathrm{O}$ & $179 \times 10^{-4}$ \\
\hline $\mathrm{MoO}_{3}$ & 0.01 & $\mathrm{Co}\left(\mathrm{NO}_{3}\right)_{2} \cdot 6 \mathrm{H}_{2} \mathrm{O}$ & $440 \times 10^{-4}$ \\
\hline
\end{tabular}

The $\mathrm{pH}$ value was measured using a digital $\mathrm{pH}$ meter (SUNTEX, SP-701, Taiwan).

The Spirulina platensis stock cultures were transferred into two 3-L flasks with cotton plugs, with $2.5 \mathrm{~L}$ of Z9 medium (as Z9 algal stock solution) and 2.5 L of PES medium (as PES algal stock solution) respectively. Samples were cultured in a plant incubator (Firstek, Taiwan). The irradiance was $170 \mu \mathrm{mol}$ photons $\bullet \mathrm{m}^{-2} \cdot \mathrm{s}^{-1}[18]$ and 12:12, $\mathrm{L}: \mathrm{D}$ photoperiod, at $35^{\circ} \mathrm{C}$ [9].

Because the algal bodies (length and cell number in trichome) of Spirulina platensis vary, a spectrophotometer (Metertek SP-830, Taiwan) was used to estimate the absorbance of the algal cultures. The optical densities of the algal cultures were determined at $650 \mathrm{~nm}$ wavelength. Subsequently, the absorbance values were transferred to biomass of day weight which was determined in $1 \mathrm{~L}$ of algal culture solution. The cells were washed 3 times with distilled water and dried at $80^{\circ} \mathrm{C}$ for $24 \mathrm{hrs}$. The experiments in this study were performed three times, and the average counts were recorded.

\section{Shift of Culture Media}

When the absorbance of Z9 and PES algal stock solution reached 2.0 , ca. $60 \mathrm{~mL}$ of $\mathrm{Z9}$ algal stock solution was transferred into five 3-L flasks with $2.5 \mathrm{~L}$ of the five media, Z9, Z9-1 Z9-2, PEF and PES, (Z9 shifted to Z9, Z9-1, Z9-2, PEF and PES), respectively. In addition, ca. $65 \mathrm{~mL}$ of the PES algal stock solution was transferred (shifted) to a 3 -L flask with 2.5
L of Z9 medium (PES shifted to Z9). The initial culture absorbance was set to 0.08 by adding the algal stock solutions. Cultures were incubated in the same plant incubator with the irradiance at $170 \mu \mathrm{mol}$ photons $\cdot \mathrm{m}^{-2} \cdot \mathrm{s}^{-1}$ and a 12:12, L:D photoperiod at $35^{\circ} \mathrm{C}$.

The culture materials were observed and photographed under light microscope (Zeiss, Axioscope) and electron microscope.

In this culture test, a Z9 culture group was remained the same therefore serving as the control group.

\section{Preparation for Electron Microscopy Study}

The algal cultures were collected in 15-ml centrifuge tubes centrifuged at $1200 \times \mathrm{g}$ for $20 \mathrm{~min}$ (HERMLE Z360K) followed by separate fixation in $0.1 \mathrm{M}$ sucrose solution containing $4 \%$ glutaraldehyde and $0.1 \mathrm{M}$ sodium cacodylate buffer $\left(\mathrm{pH} \mathrm{7.0)}\right.$ at $4^{\circ} \mathrm{C}$ for $2 \mathrm{hrs}$. They were then rinsed twice with a $0.1 \mathrm{M}$ sodium cacodylate buffer containing $10 \mathrm{mM} \mathrm{CaCl}_{2}$, and sucrose concentration successively reduced to $0.05 \mathrm{M}$. This treatment was followed by two rinses by a pure (sucrose-free) $0.1 \mathrm{M}$ sodium cacodylate buffer containing $10 \mathrm{mM} \mathrm{CaCl}_{2}$.

Post-fixation was performed with $2 \% \mathrm{OsO}_{4}$ in $0.1 \mathrm{M}$ sodium cacodylate buffer containing $10 \mathrm{mM} \mathrm{CaCl}_{2}$ for $1 \mathrm{hr}$ at $4^{\circ} \mathrm{C}$.

Thereafter, all materials were rinsed four times with a sodium cacodylate buffer containing $10 \mathrm{mM} \mathrm{CaCl}_{2}$, three times 
Table 3. The initial slopes (from day 1 to day 23) of the growth curves and the growth rates of all the culture groups. The formula of growth rate is: $\mu=\ln x_{2}-\ln x_{1} / d_{2}-d_{1}$, where $x_{1}$ and $x_{2}$ are the absorbance of day intervals $d_{1}$ and $d_{2}$.

\begin{tabular}{lllllcc}
\hline Culture groups & Z9 & Z9-1 & Z9-2 & Z9-PES & Z9-PEF & PES-Z9 \\
Initial slopes & 0.08 & 0.089 & 0.095 & 0.139 & 0.121 & 0.152 \\
Growth rates & 1.25 & 1.16 & 0.89 & 0.75 & 0.7 & 1.31 \\
\hline
\end{tabular}

Table 4. The average biomass of all groups at day 40 of culture.

\begin{tabular}{lcccccc}
\hline Culture groups & Z9 & Z9-1 & Z9-2 & Z9-PES & Z9-PEF & PES-Z9 \\
Gram of dried & 8.13 & 6.91 & 5.1 & 4.2 & 5.8 & 10.29 \\
weight $/ \mathrm{L}$ & $( \pm 0.26)$ & $( \pm 0.24)$ & $( \pm 0.22)$ & $( \pm 0.22)$ & $( \pm 0.25)$ & $( \pm 0.28)$ \\
\hline
\end{tabular}

with aqueous ethanol (50\%) and gradually dehydrated in ethanol $(50,70,85,95,100 \%)$. Dehydrated materials were prepared for transmission electron microscope (TEM, Hitachi HF100) and scanned by electron microscope (SEM, Hitachi S-800).

For TEM, some dehydrated materials were rinsed in propylene oxide (three times, $30 \mathrm{mins}$ each), followed by infiltration in propylene oxide-Spurr's resin in a decreasing ratio from 2:1 (2 parts propylene oxide: 1 part Spurr's resin) to 1:1, each for 4 hrs. Samples were then suspended in pure Spurr's resin for two days at $4^{\circ} \mathrm{C}$ in darkness before embedding in Spurr's resin [14]. The thin-sections were stained with uranyl acetate and lead citrate according to Smith and Croft [13].

For SEM, some dehydrated materials were dropped onto specimen holders and then dried with a critical-point-drying machine (Hitachi-HCP-1). Finally, they were coated onto an ion coater (Joel, JCF-1100E) for 220 s.

\section{RESULTS}

As shown in Fig. 1, after 40 days of culture, the absorbance of the Z9, Z9-1 and PES-Z9 culture groups were above 3.0. The PES-Z9 culture group exhibited the best growth condition. It took only 13 days for the PES-Z9 group to reach 3.0 of absorbance, and reached as high as 3.5 (the biomass was 10.29 g dry weight/L) at day 40 of culture, and still showed a trend toward increase. The Z9 culture group showed the slowest growth increase (the initial slope) until day 17. The Z9 group absorbance reached 3.0 at the end of culture (The biomass was $7.13 \mathrm{~g}$ dry weight/L as shown in Table 4). The Z9-PES, Z9PEF and Z9-2 culture groups never reached 3.0 and showed a decrease in growth from day 24 for Z9-PEF and Z9-PES, and from day 25 for Z9-2. As shown in Table 4, the biomass of those groups were under $6.0 \mathrm{~g}$ dry weight/L.

As shown in Fig. 1 and Table 3, Z9 to PES (the Z9-PES culture group) and PES to Z9 (the PES-Z9 culture group) exhibited better initial slopes than the other culture groups. Over 23 days of culture the initial slope of the PES-Z9 culture was the best.

The initial slopes for the Z9-PES and Z9-PEF culture groups were better than Z9, Z9-1 and Z9-2. Alga cultured in

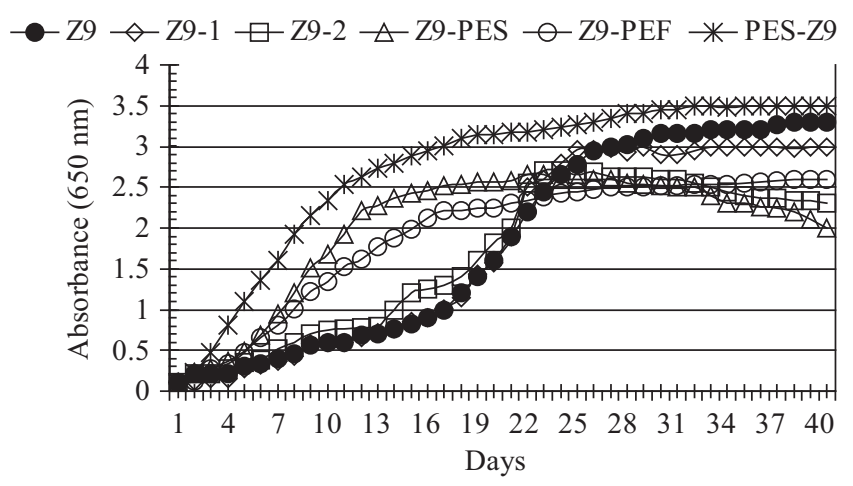

Fig. 1. Growth curves of Spirulina platensis cultured in six different batch culture groups. Culture conditions were $35^{\circ} \mathrm{C}, 170 \mu \mathrm{mol}$ photons $\bullet \mathrm{m}^{-2} \cdot \mathrm{s}^{-1}$ and a 12:12, $\mathrm{L}: \mathrm{D}$ photoperiod.

Provasoli modified media could accelerate cell division, which resulted in an initial phase with the best initial growth curves slopes. In contrast, the growth rates of the Z9, Z9-1 and Z9-2 culture groups were better than Z9-PES and Z9-PEF at the end of culture. Zarrouk modified media were the most suitable ones for steady growth, and produced the better biomass at the end of culture. The PES-Z9 culture group combined the two best factors, the best initial growth slope and the best growth rate, and therefore produced the best biomass.

The final algal filaments from all culture groups were long (ca. $433 \mu \mathrm{m}$ in length) with ten or more spirals (Fig. 2). The trichome, a chain of cells within the thin filament sheath (Fig. 3) were ca. $6.5 \mu \mathrm{m}$ in diameter. In the media shift tests, the PES-Z9 culture group, fragmented sections, the hormogonia (Fig. 4) appeared on the long algal filaments within 5 days of culture after the media were shifted. All of the long filaments then became many short filaments (Fig. 5). However, the media shift between the same incubated media, such as from PES to PEF and from Z9 to Z9-1or Z9-2 rarely induced the formation of hormogonia in this alga.

The media shift also resulted in morphological changes in the newly formed short algal filaments after 7 days of culture. Scanning electron microscope (SEM) observation found that the newly formed short filaments straightened and became less spiral (Fig. 6) in contrast to the spiral filament (Fig. 7) nor- 


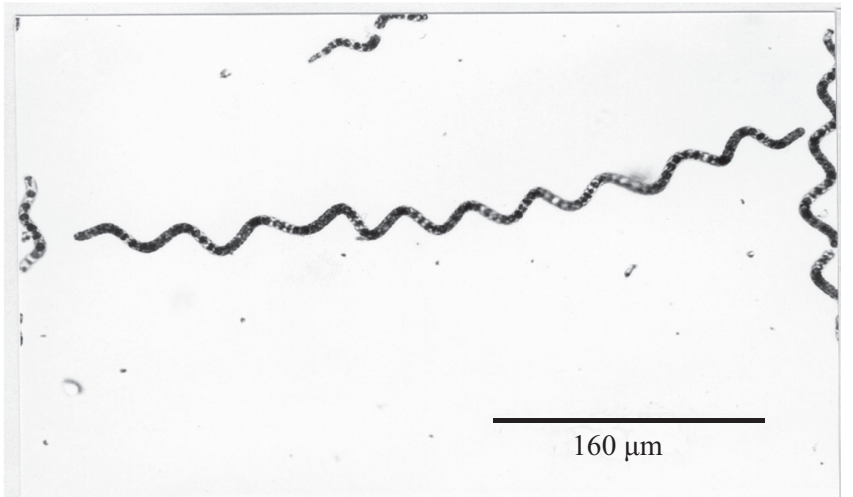

Fig. 2. The long filamentous Spirulina platensis after 40 days of culture.

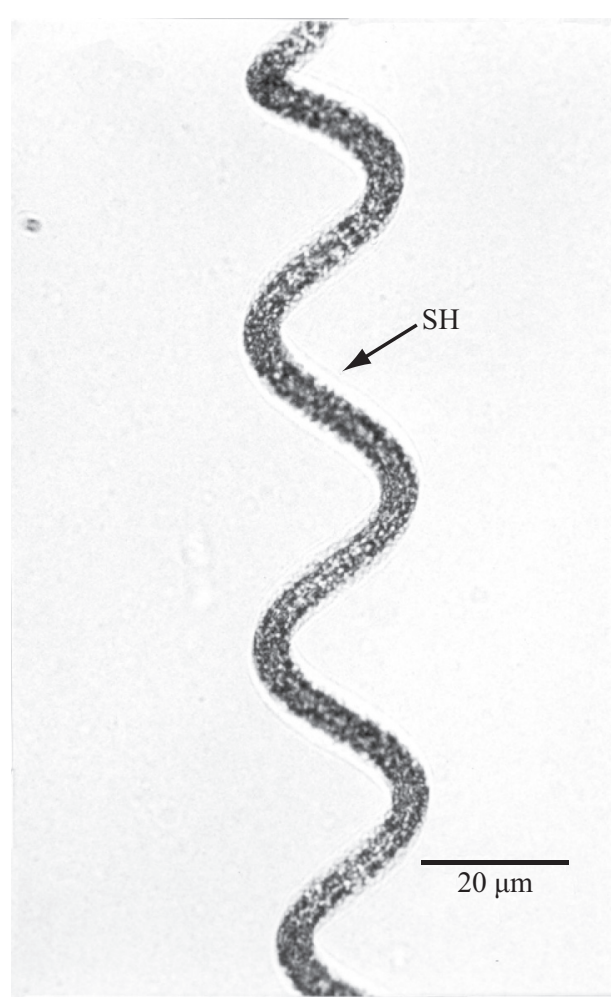

Fig. 3. A chain of cells (the trichome) within the thin sheath (SH) composed the filament of Spirulina platensis. The diameter of the filament is ca. $6.5 \mu \mathrm{m}$.

mally found on Spirulina platensis cultured in Z9 medium. These filaments were also observed under transmission electron microscope. It was found that the ingrowths (cell division) (Fig. 8) frequently appeared in the newly formed filament in contrast to the more spiral filament (Fig. 9).

\section{DISCUSSION}

The filamentous alga Spirulina is common in lakes with a high soda content and high $\mathrm{pH}$. Spirulina platensis can therefore be clearly defined as an obligate alkaliphile [2]. Cultures

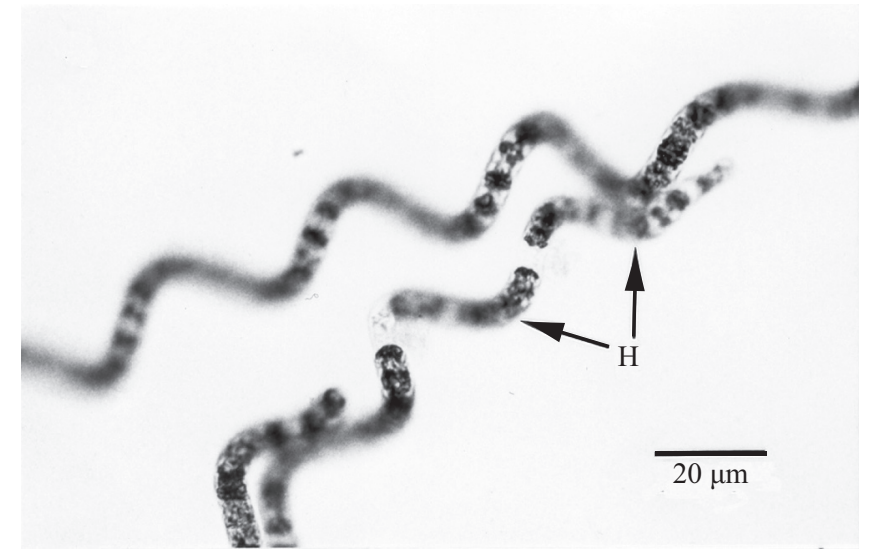

Fig. 4. Hormogonia (H) appeared from the long algal filaments after the media were shifted within 5 days of culture. The length of the hormogonia is ca. $40-55 \mu \mathrm{m}$.

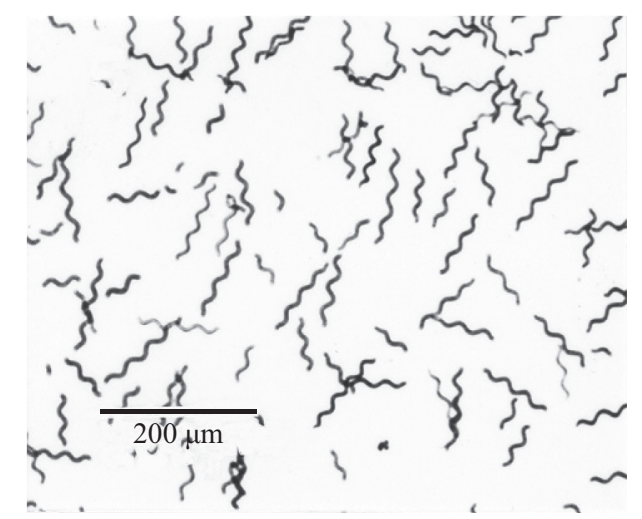

Fig. 5. Many new short algal filaments were produced after the media were shifted. The long filaments no longer existed, after the media shifted within 7 days of culture.

of this alga are more exceptional than other microalgal cultures. In the present study, it was clearly found that the bicarbonate, $\mathrm{NaHCO}_{3}$, was important for sustained Spirulina cultures. This may be because $\mathrm{NaHCO}_{3}$ maintains the high $\mathrm{pH}$ environment and osmoticum required by the Spirulina. In contrast to the Z9 (Zarrouk medium) culture group, the Na$\mathrm{HCO}_{3}$ concentration in the Z9-1 culture group was reduced to half and the Z9-2 culture group was without $\mathrm{NaHCO}_{3}$. Both groups did not exhibit enhanced initial growth slopes and their growth rates were less than the Z9 culture group at the end of culture (as shown in Table 3). The PEF culture group, with added high $\mathrm{NaHCO}_{3}(16.8 \mathrm{~g} / \mathrm{L})$ content, showed a small increase in the initial slope better growth rate than the Z9-1 and Z9-2 culture groups at the end of culture. Schlesinger et al. [12] also reported that $S$. platensis was alkaliphile and required high sodium content to survive in alkaline environments. Diluted seawater was frequently used instead of $\mathrm{NaHCO}_{3}$ in some commercial mass cultures for reducing costs in Taiwan. However, the results from the present study indicate that Spirulina cultures using $\mathrm{NaHCO}_{3}$ for media produced a better 


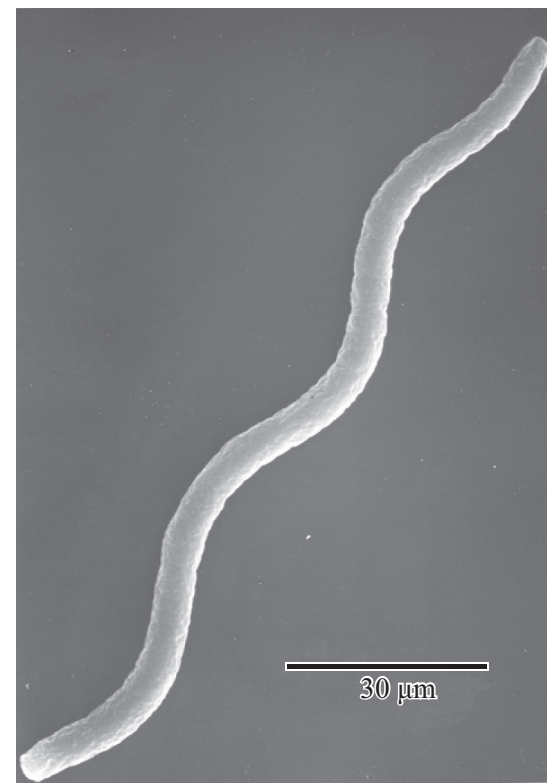

Fig. 6. The straight short filament with slight spiral after the media were shifted within 5 days of culture.

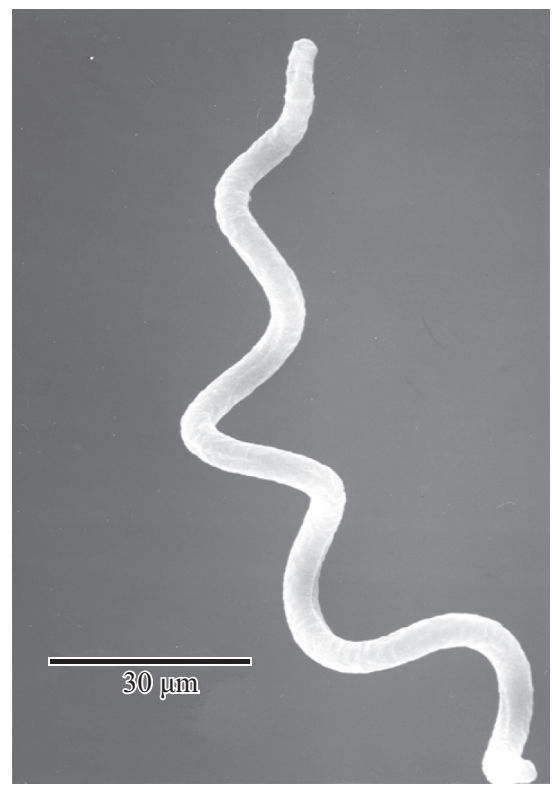

Fig. 7. Ten-day-old normal spiral filament without the media shift treatment cultured in Zarrouk media.

biomass than cultures based on diluted seawater. This result was consistent with the study by Schlesinger et al. [12]. They reported that sodium deprivation caused rapid death in $S$. platensis.

High $\mathrm{NaHCO}_{3}$ content has the additional function of excluding medium contamination by other organisms. Vonshak et al. [17] reported that the contaminant, Chlorella, declined rapidly when $16 \mathrm{~g} / \mathrm{L}$ of bicarbonate was added to the medium.

Although Spirulina platensis favors alkaline environments, even at high external $\mathrm{pH}$ values, it is capable of maintaining an

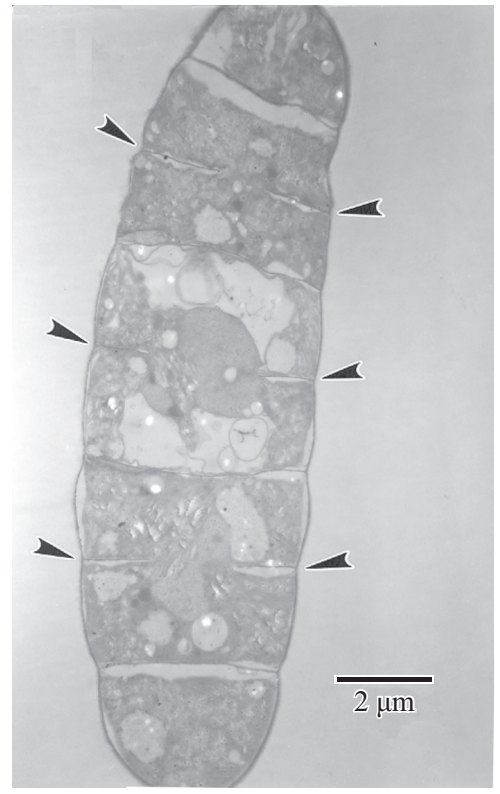

Fig. 8. Ingrowths (arrow heads) frequently appeared in the short slight spiral filament.

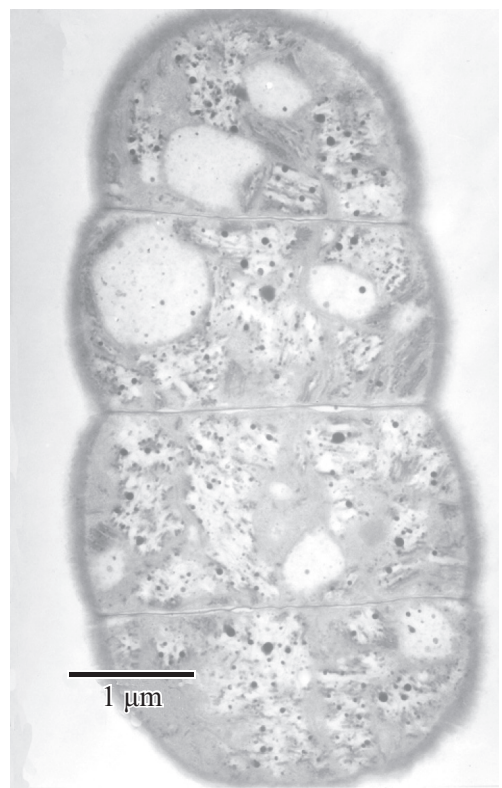

Fig. 9. The normal spiral filament shown without the ingrowths.

appreciable $\mathrm{pH}$ gradient across its cytoplasmic membrane [5]. The dependency on active sodium-proton antiporters for maintenance of a relatively acidic internal $\mathrm{pH}[8]$ that is energetically depleted may delay the logarithmic phase of the growth, causing a lower initial growth slope as shown by the results from alga that were cultured in the alkaline Zarrouk modified media in the present study.

The PES-Z9 culture group biomass was the highest in the present study. This was because the media shift accelerated the algal cell division and formed hormogonia that fragment 
had therefore increased the rate of the initial growth slopes. Although the cultures were first cultivated in PES media, they were later cultivated in Z9 media. The alga growth increased in its' new favorable environment. The highest produced biomass (i.e. $10.29 \mathrm{~g}$ dry weight $/ \mathrm{L}$ ) of the present study was consistent with the results of the complex photobioreactor cultures by Qiang et al. [11]. The present study used normal batch cultures, which were the simplest Spirulina cultures with the lowest cost. It is important to point out the cost of high-tech algal cultures determines the commercial viability of a production crop.

The media shift in the present study could alter the morphologies of the algal filaments after they were shifted from Provasoli medium to Zarrouk within 5 days of culture. This was evidence in the SEM and TEM observations, in which the short filaments produced many ingrowths that straightened the spiral filament into a less spiral form. In contrast, when the growth of $S$. platensis was inhibited by ethyl methane-sulphonate, their filaments became varied lengths with more spirals [4]. Mühling et al. [7] also reported the helix orientation altered in Arthrospira when the environmental factor changed, such as temperatures.

A combination of Zarrouk and Provasoli media produced a new medium for ultrahigh-density culture of Spirulina platensis. This combination complicated the concentrations of the nutrient elements considerably, resulting in unstable growth with many unknown problems that require further study. The macro-elements of these two media are similar, but the microelements of the Zarrouk medium are more complex than those in the Provasoli medium. Provasoli medium includes thiamin $\mathrm{HCl}$, biotin and vitamin 12 . I supposed that the vitamins made the alga obtain active cell division when cultured in Provasoli medium. The high $\mathrm{NaHCO}_{3}$ content in the Zarrouk medium restrained the vitamin effects when they had been added.

In conclusion, the Spirulina media shift cultures were easy to operate and ready to use with the lowest cost and high biomass in comparison with other culture methods (i.e. raceway, closed photobioreactors etc.). This finding could facilitate the small scale culture of Spirulina platensis in laboratory for the materials for further scientific study, and may apply to out door mass culture for commercial production.

\section{ACKNOWLEDGMENTS}

The author sincerely thanks the eviewers for their kindly and helpful suggestions. Financial support from NSC grants 99-2321-B-019-005, COA grants 99-AS-5.3.1-ST-aQ, and NTOU-RD-AA-2010-102022, Taiwan is greatly appreciated.

\section{REFERENCES}

1. Ayehunie, S., Belay, A., Baba, T. W., and Ruprecht, R. M., "Inhibition of
HIV-1 replication by an aqueous extract of Spirulina platensis (Arthrospira platensis)," Journal of Acquired Immune Deficiency and Syndromes Human Retrovirology, Vol. 18, pp. 7-12 (1998).

2. Belkin, S. and Boussiba, S., "Resistance of Spirulina platensis to ammonia at high $\mathrm{pH}$ values," Plant Cell Physiology, Vol. 32, pp. 953-958 (1991).

3. Chen, Y. C., "Immobilization of twelve benthic diatom species for longterm storage and as feed for post-larval abalone Haliotis diversicolor," Aquaculture, Vol. 263, pp. 97-106 (2007).

4. Cui, H. P., Wang, Z. P., and Xu, B., "The effects of ethyl methanesulphonate on the growth and morphology of Spirulina platensis," Journal of Zhejian Agriculture, Vol. 23, pp. 645-648 (1997).

5. Krulwich, T. A. and Guffanti, A. A., "Alkalophilic bacteria," Annual Review of Microbilogy, Vol. 43, pp. 435-463 (1989).

6. Mishima, T., Murata, J., Toyoshima, M., Fujii, H., Nakajima, M., Hayashi, T., Kato, T., and Saiki, I., "Inhibition of tumor invasion and metastasis by calcium spirulina (Ca-SP), a novel sulfated polysaccharide derived from a blue-green alga, Spirulina platensis," Clinical and Experimental Metastasis, Vol. 16, pp. 541-550 (1998).

7. Mühling, M., Harris, N., Belay, A., and Whitton, B. A., "Reversal of helix orientation in the cyanobacterium Arthrospira," Journal of Phycology, Vol. 39, pp. 360-367 (2003).

8. Padan, E., Zilberstein, D., and Schuldiner, S., "pH homeostasis in bacteria," Biochimica et Biophysica Acta, Vol. 650, pp. 151-166 (1981).

9. Payer, H. D., Chiemvichak, Y., Hosakul, K., Kongpanichkul, C., Kraidej, L., Nguitragul, M., Reungmanipytoon, S., and Buri, P. "Temperature as an important climatic factor during mass production of microscopic algae," in: Schelef, G. and Soeder, C. J. (Eds.), Algae Biomass: Production and Use, Elsevier North Holland biomedical press, Amsterdam, pp. 389-399 (1980).

10. Provasoli, L., "Media and products for the cultivation of marine algae," in: Watanabe, A. and Hattori, A. (Eds.), Culture and Collections of Algae, The Japanese Society of Plant Physiologists, Tokyo, pp. 63-75 (1968).

11. Qiang, H., Guterman, H., and Richmond, A., "Physiological Characteristics of Spirulina platensis (Cyanobacteria) cultured at ultrahigh cell densities," Journal of Phycology, Vol. 32, pp. 1066-1073 (1996).

12. Schlesinger, P., Belkin, S., and Boussiba, S., "Sodium deprivation under alkaline conditions causes rapid death of the filamentous cyanobacterium Spirulina platensis," Journal of Phycology, Vol. 32, pp. 608-613 (1996).

13. Smith, M. and Croft, S., "Embedding and thin section preparation," in: Harris, J. R. (Ed.), Electron Microscopy in Biology, IRL Press, Oxford, New York, Tokyo, pp. 17-37 (1991).

14. Spurr, A. R., "A low viscosity epoxy resin embedding medium for electron microscopy," Journal of Ultrastructure Research, Vol. 26, pp. 31-43 (1969).

15. Torzillo, G., Bernardini, P., and Masojídek, J., "On-line monitoring of chlorophyll fluorescence of assess the extent of photoinhibition of photosynthesis induced by high oxygen concentration and low temperature and its effect on the productivity of outdoor cultures of Spirulina platensis (Cyanobacteria)," Journal of Phycology, Vol. 34, pp. 504-510 (1998).

16. Vonshak, A., Abeliovich, A., Boussiba, S., Arad, S., and Richmond, A., "Production of Spirulina biomass: Effects of environmental factors and population density," Biomass, Vol. 2, pp. 175-185 (1982).

17. Vonshak, A., Boussiba, A., Abeliovich, A., and Richmond, A., "Production of Spirulina biomass: maintenance of monoalgal culture outdoors," Biotechnology and Bioengineering, Vol. 15, pp. 341-349 (1983).

18. Vonshak, A. and Guy, R., "Photoadaptation, photoinhibition and productivity in the blue-green alga, Spirulina platensis grown outdoors," Plant Cell and Environment, Vol. 15, pp. 613-616 (1992).

19. Zarrouk, C., Contributioná l'étude d'une cyanophycée. Influence de divers facteurs physiques et chimiques sur la croissance et la photosynthése de Spirulina maxima, Ph.D. Thesis, Ecole des Hautes Etudes en Sante Publique, Universitéde Paris (1966). 